CONTINUED EVALUATION OF THE HYBRID FLOATING BRUSH SEAL (HFBS)

Scott B. Lattime, Jack Braun, and Fred K. Choy

B\&C Engineering Associates, Inc.

Akron, Ohio

Robert C. Hendricks and Bruce M. Steinetz

National Aeronautics and Space Administration

Glenn Research Center

Cleveland, Ohio

\title{
CONTINUED EVALUATION OF THE HYBRID FLOATING BRUSH SEAL (HFBS)
}

\author{
S.B. Lattime \\ M.J. Braun \\ F.K. Choy
}

B\&C Engineering Associates, Inc.

Akron, OH, USA

R.C. Hendricks

B.M. Steinetz

NASA Lewis Research Center

Cleveland, OH, USA 


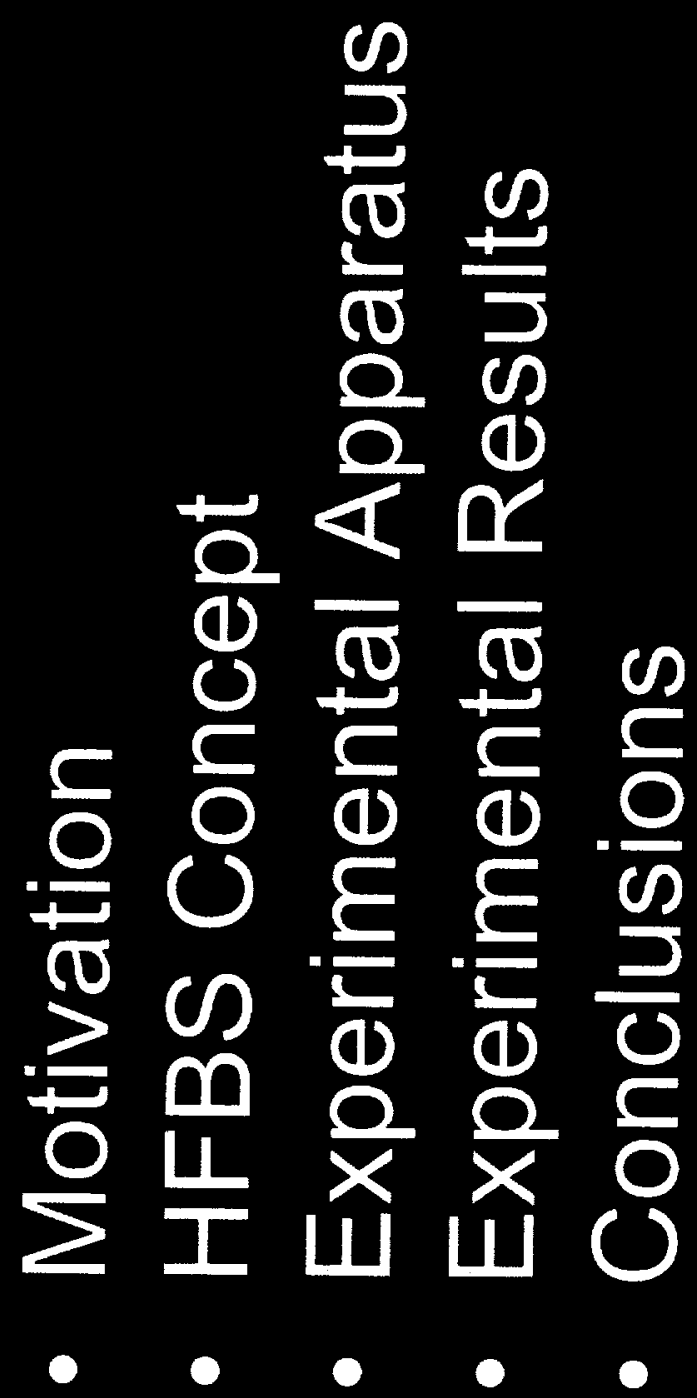




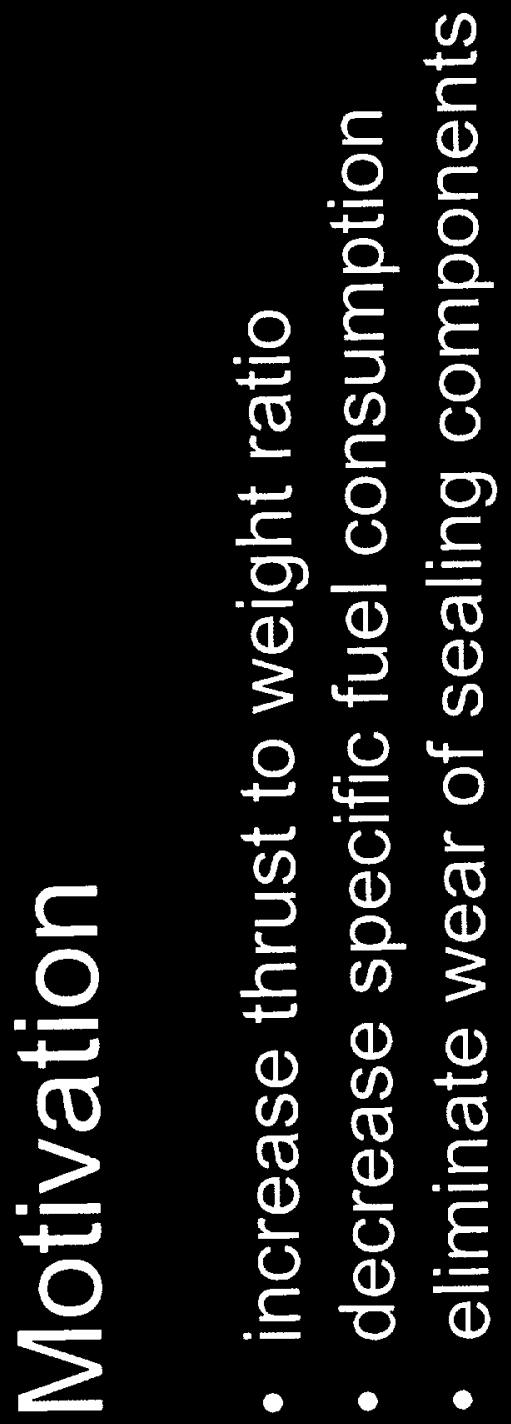




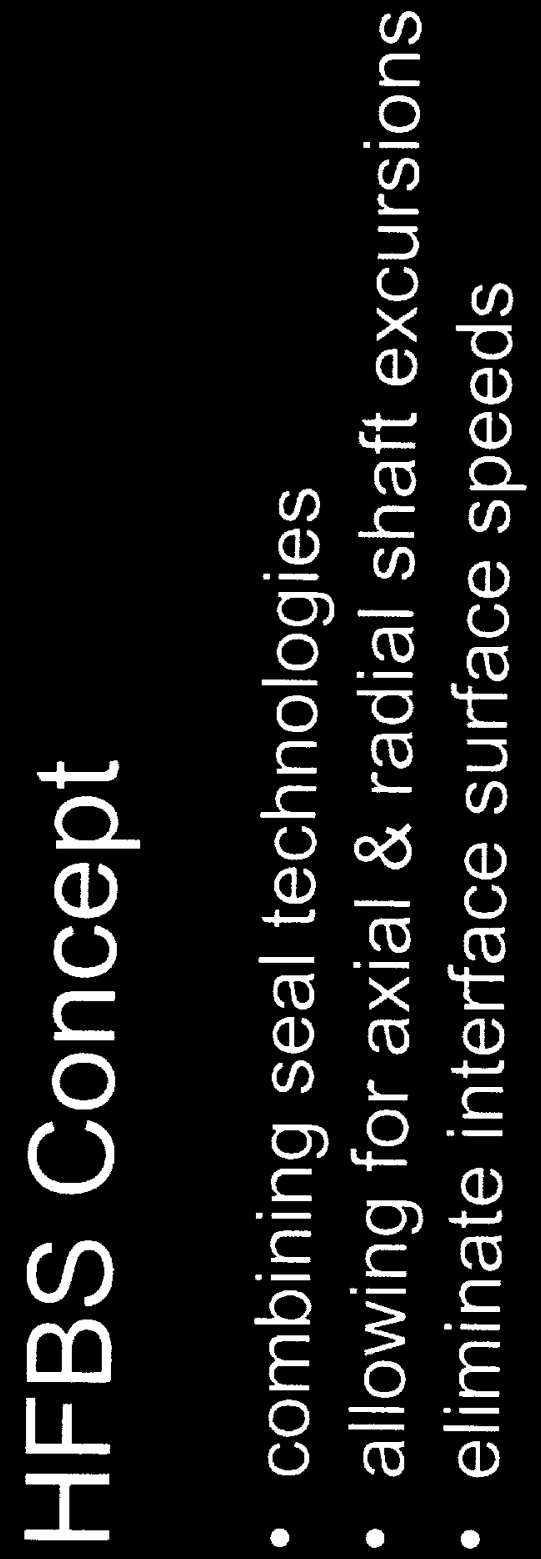




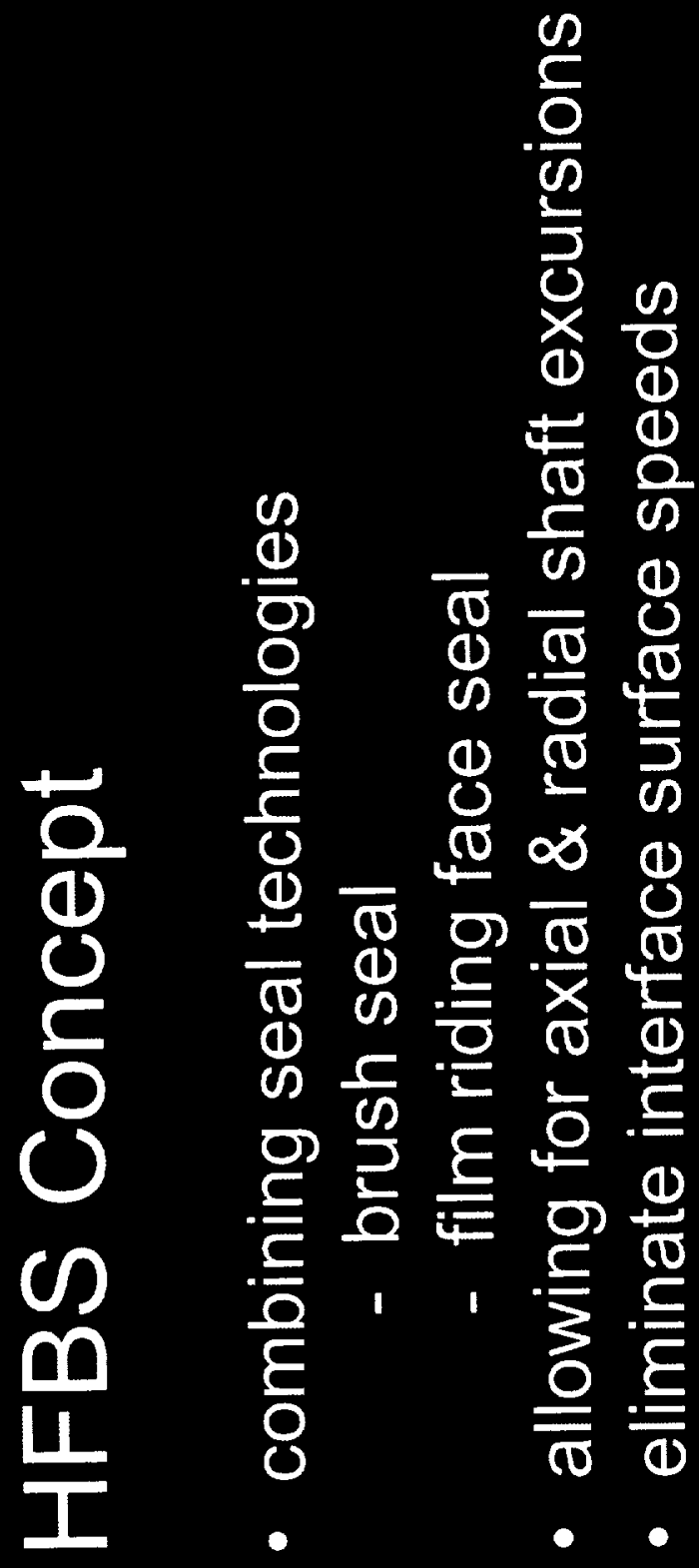




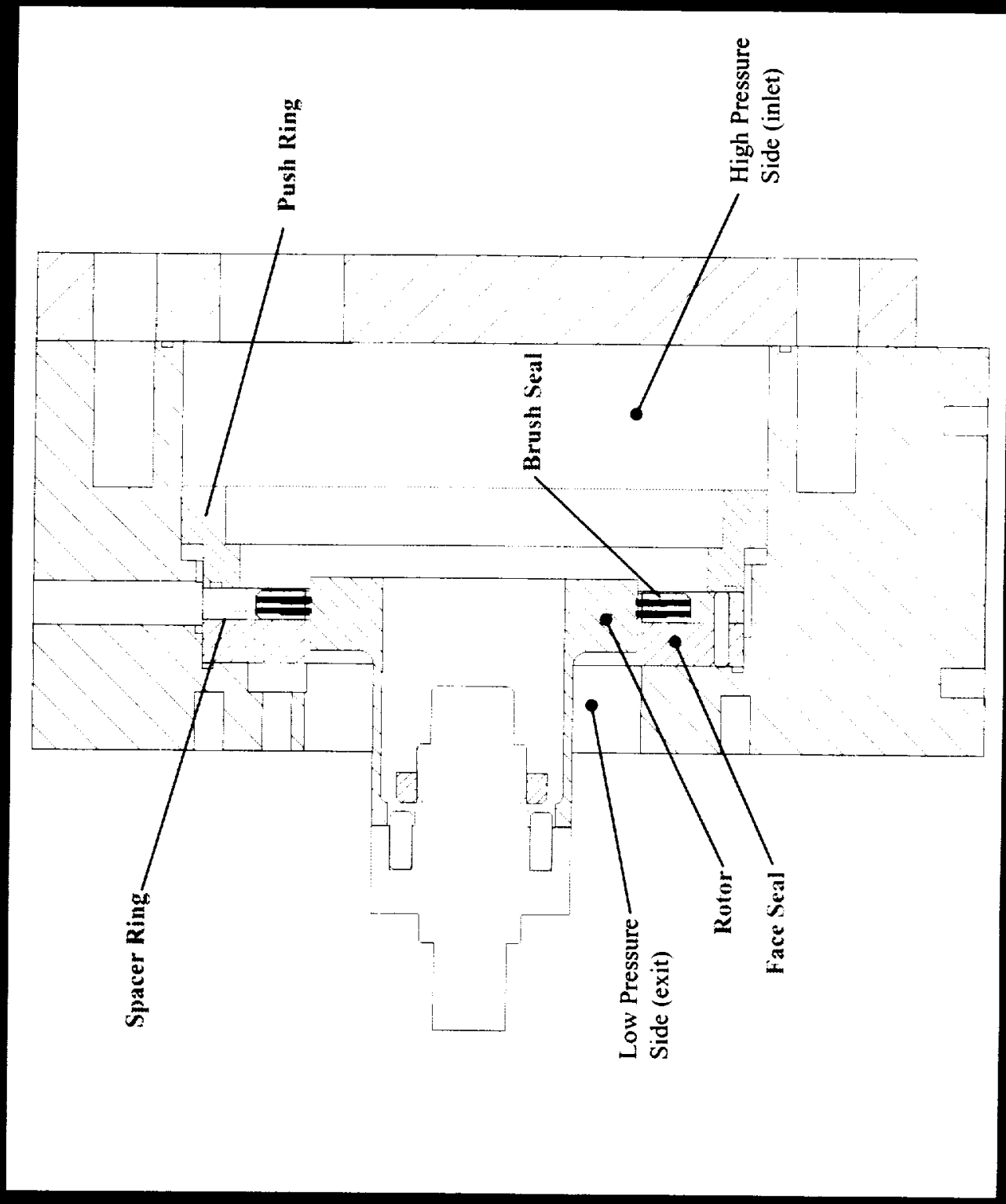




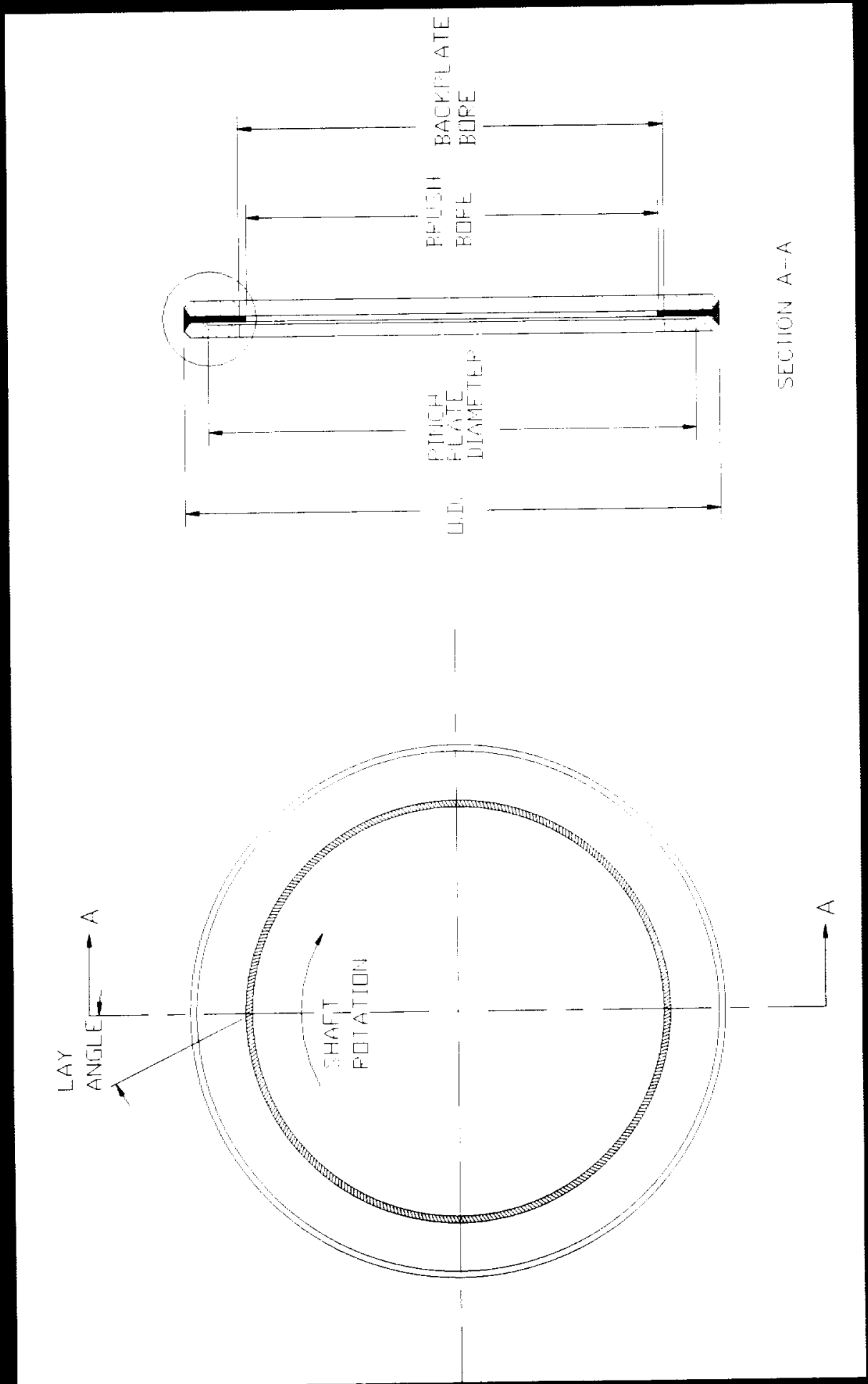




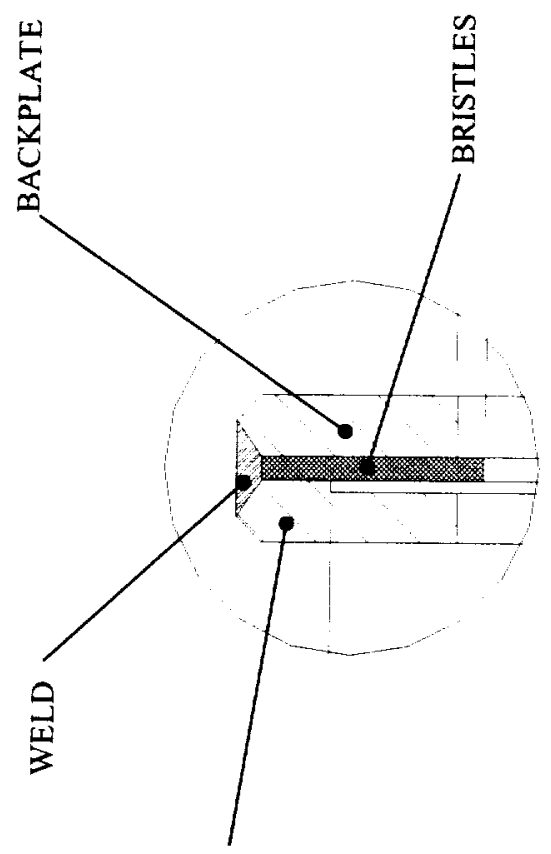

岕 


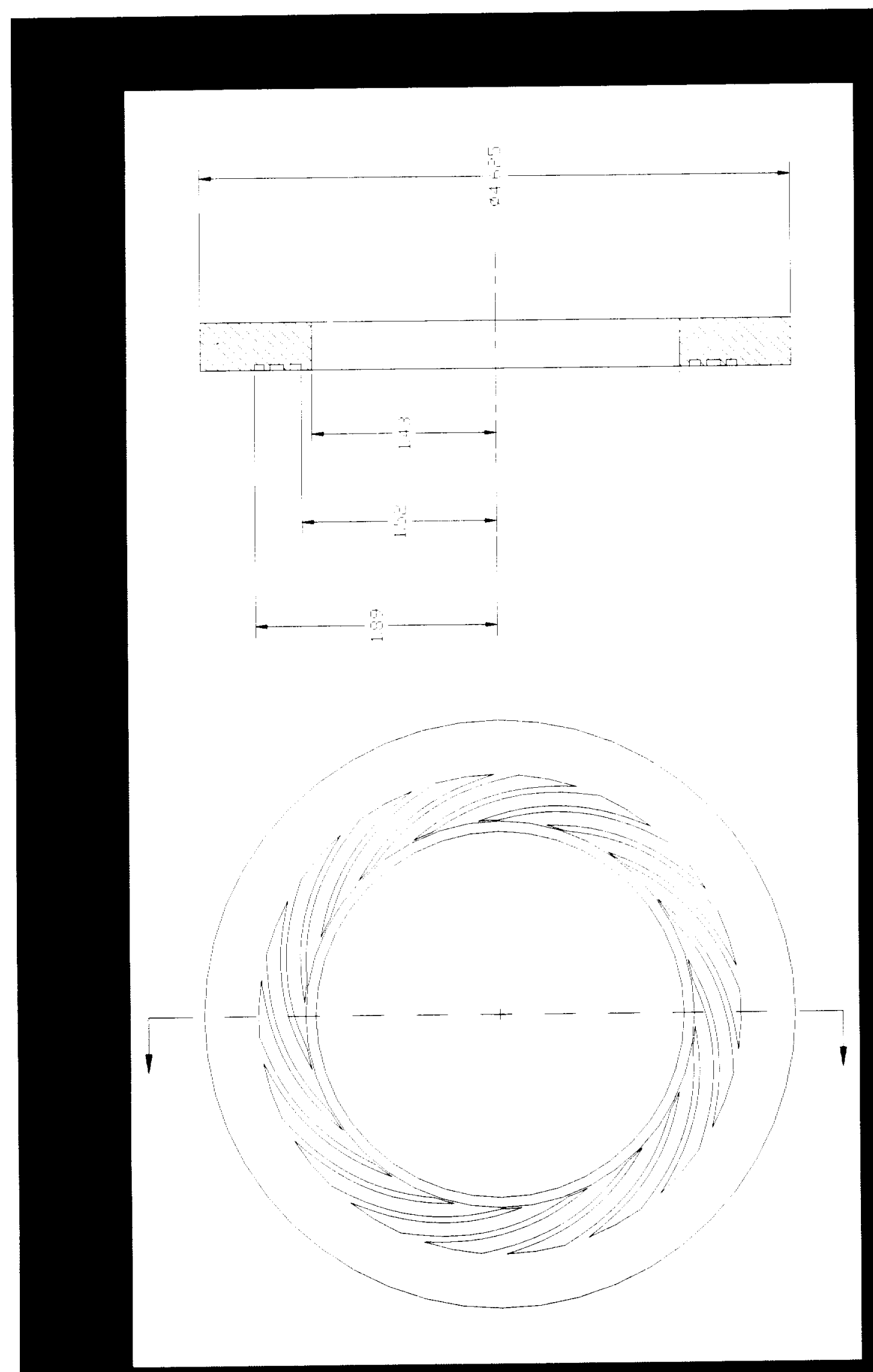




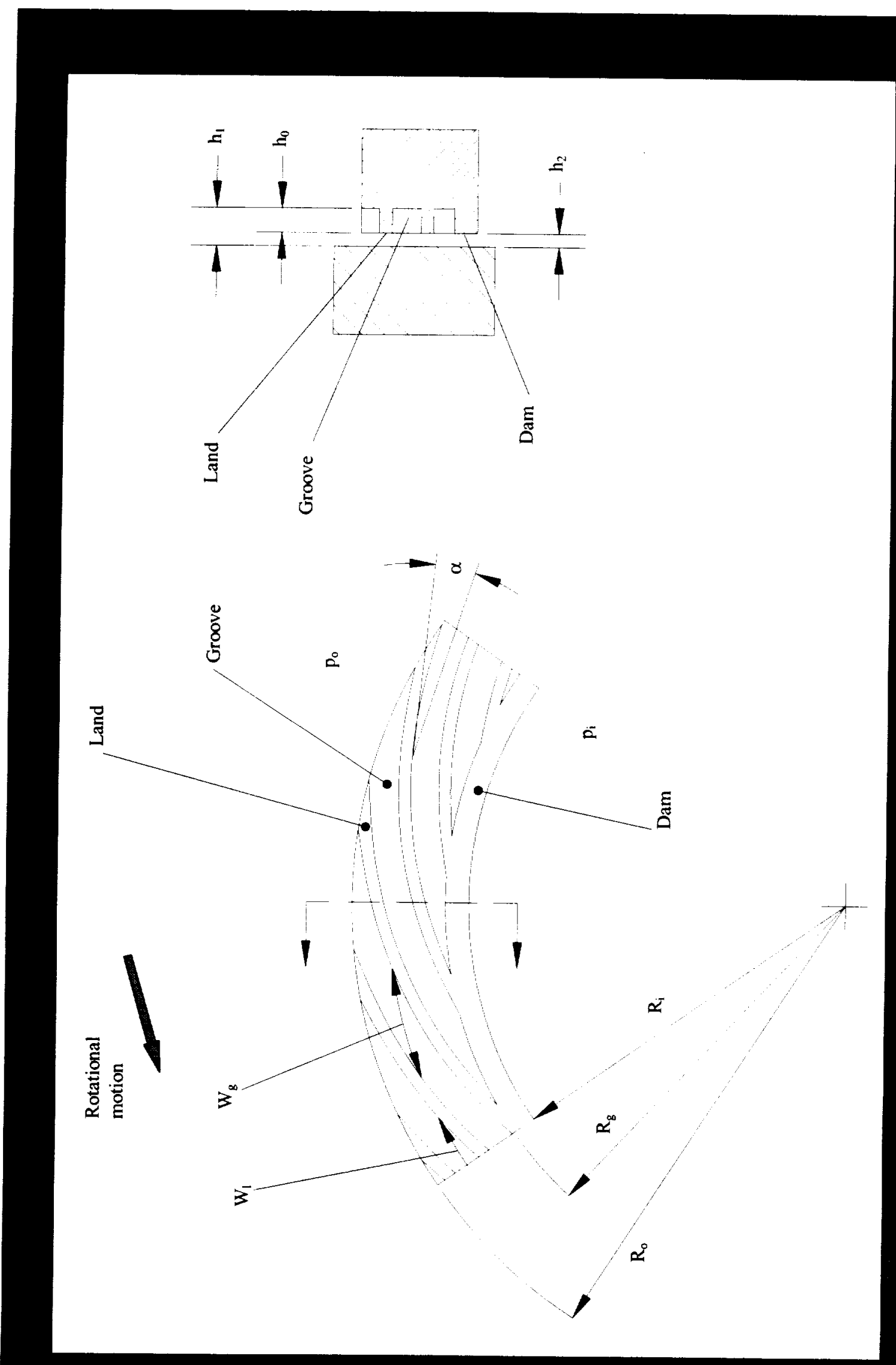




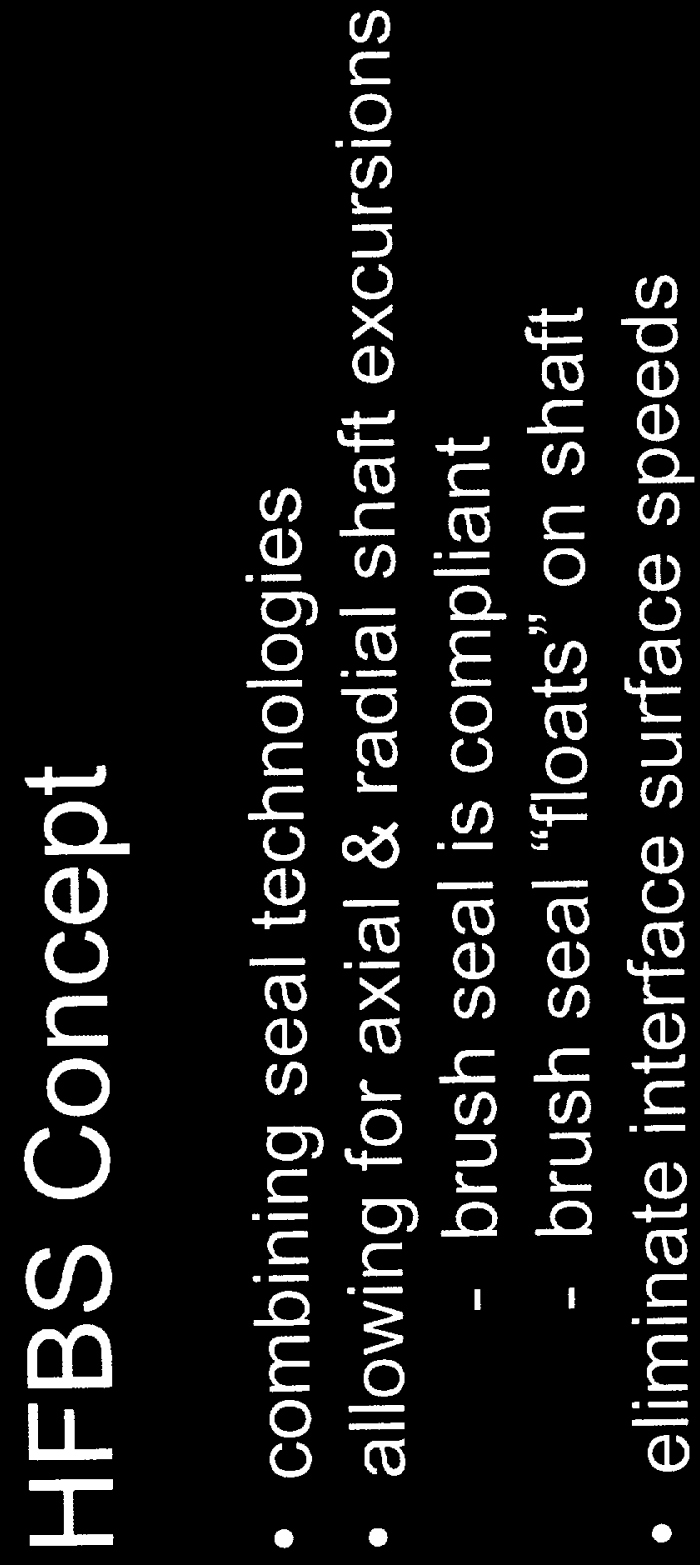




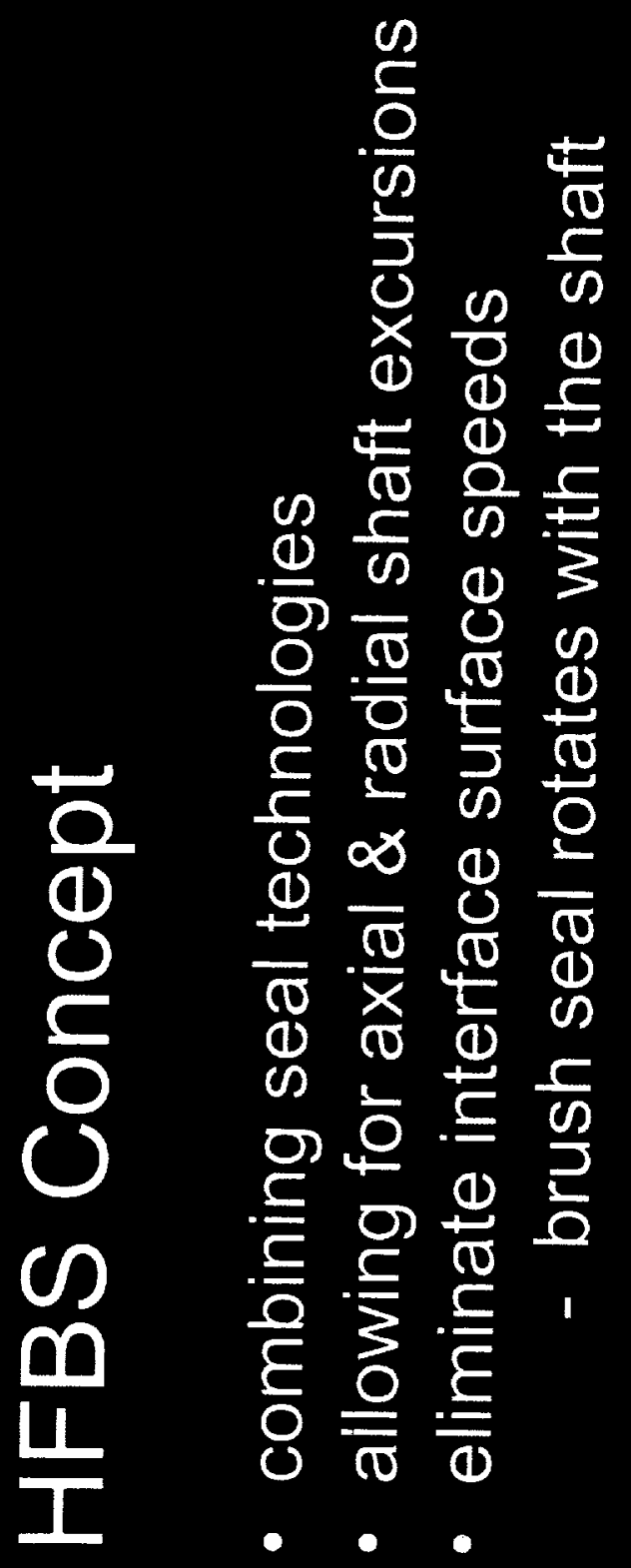




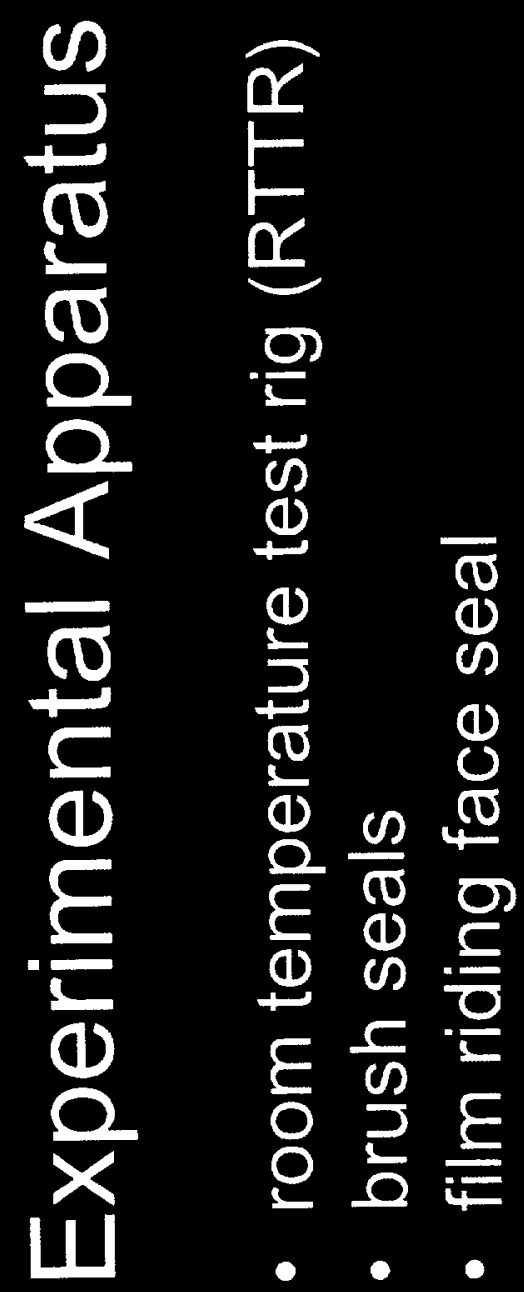




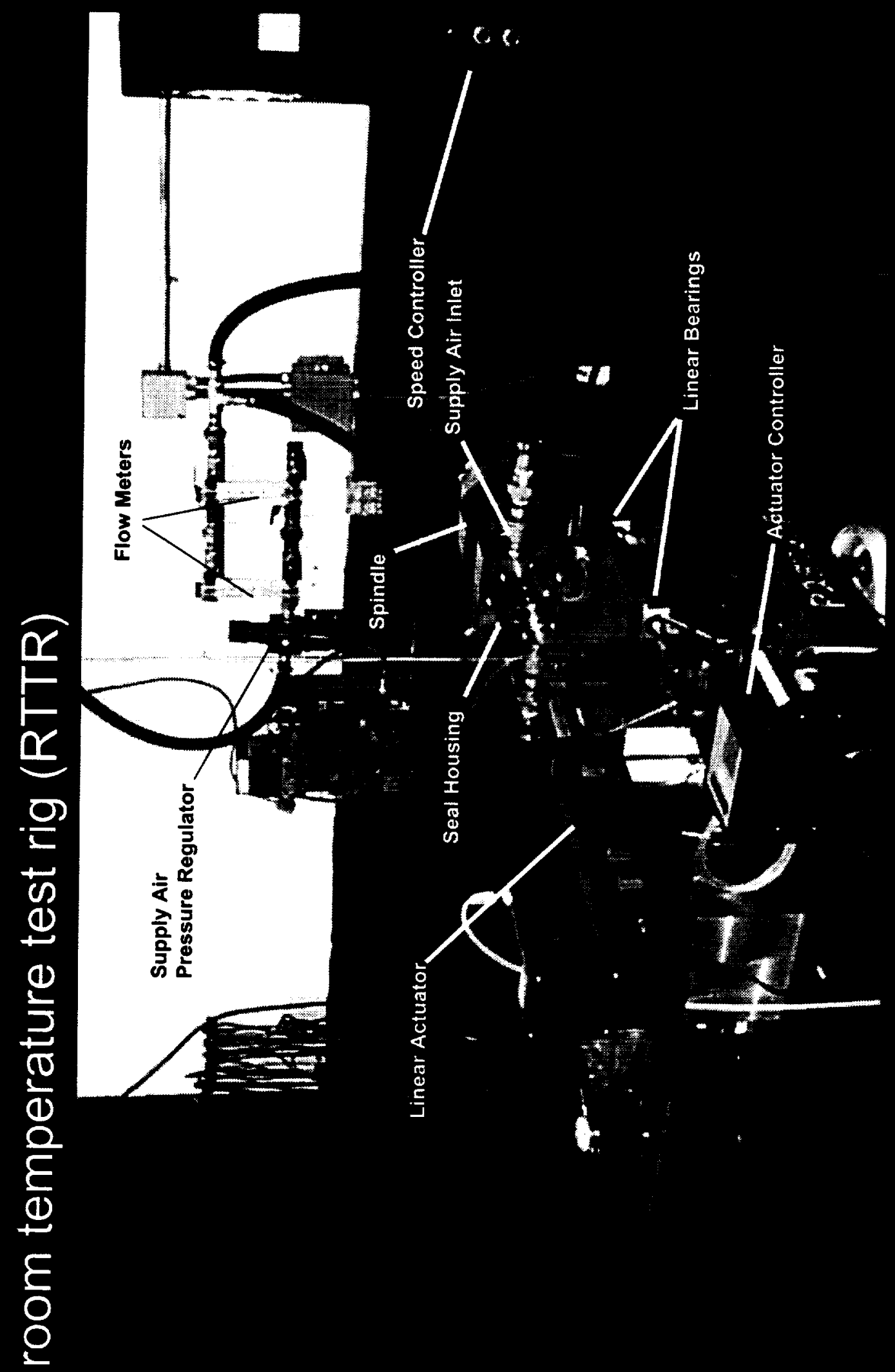




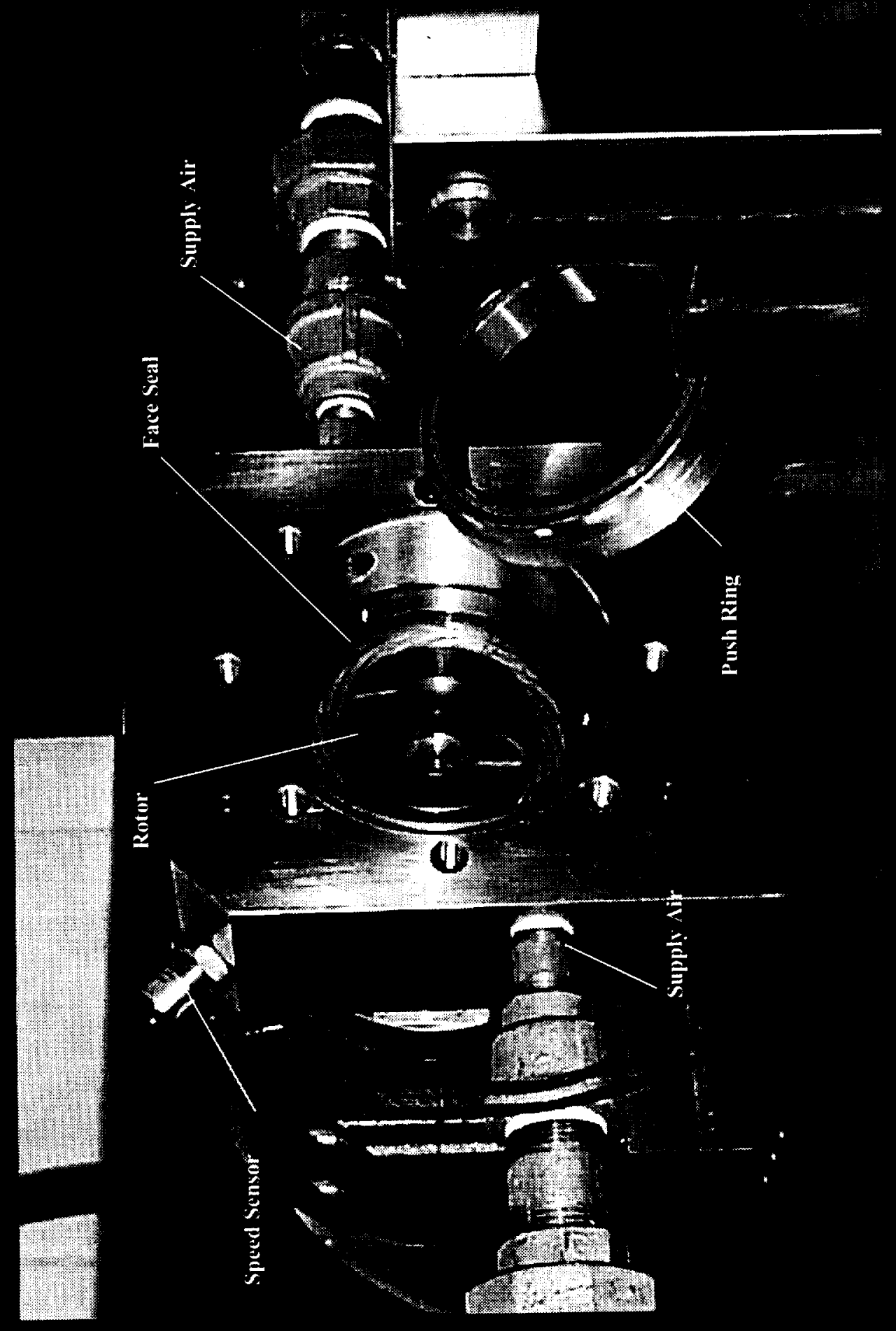




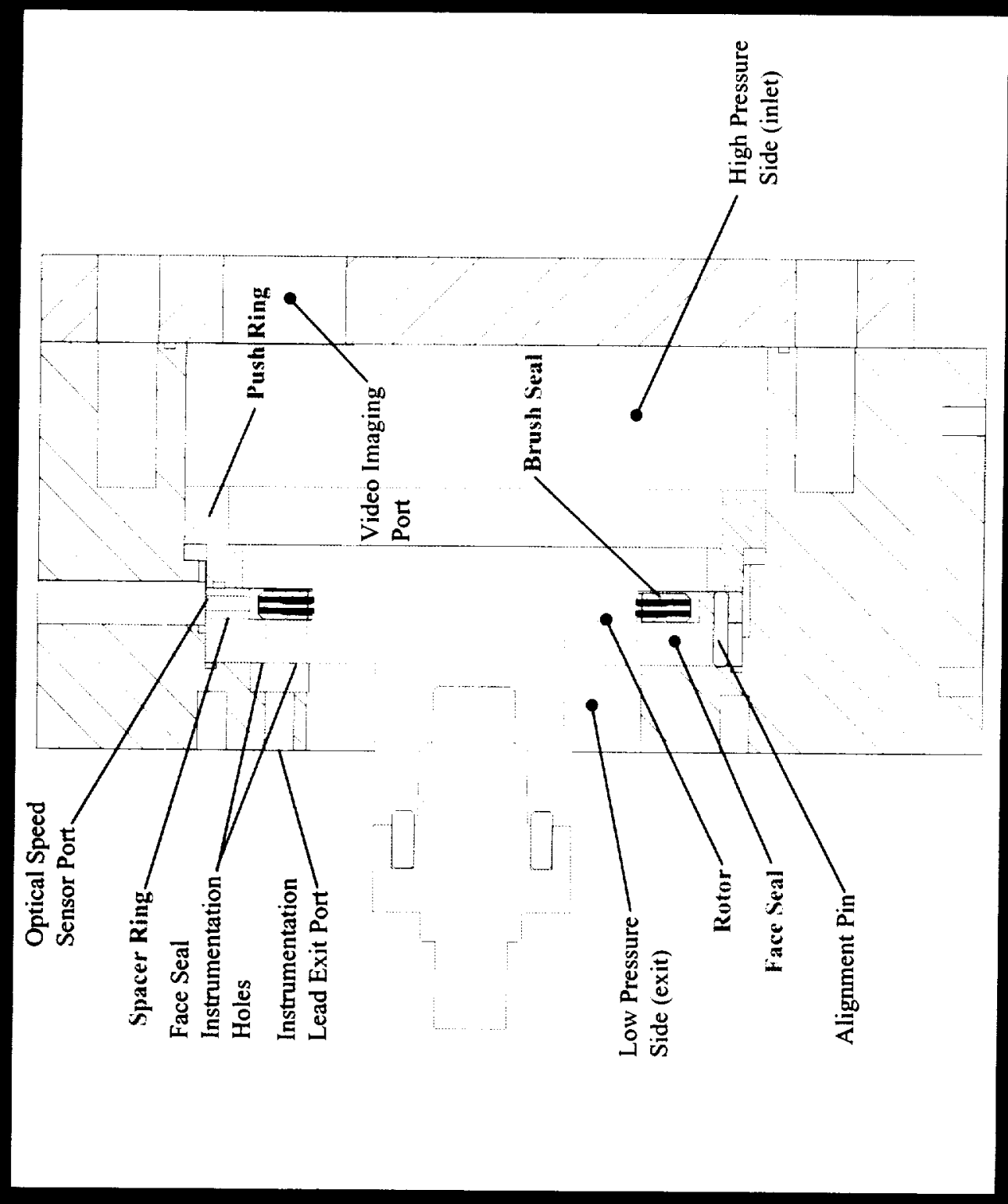




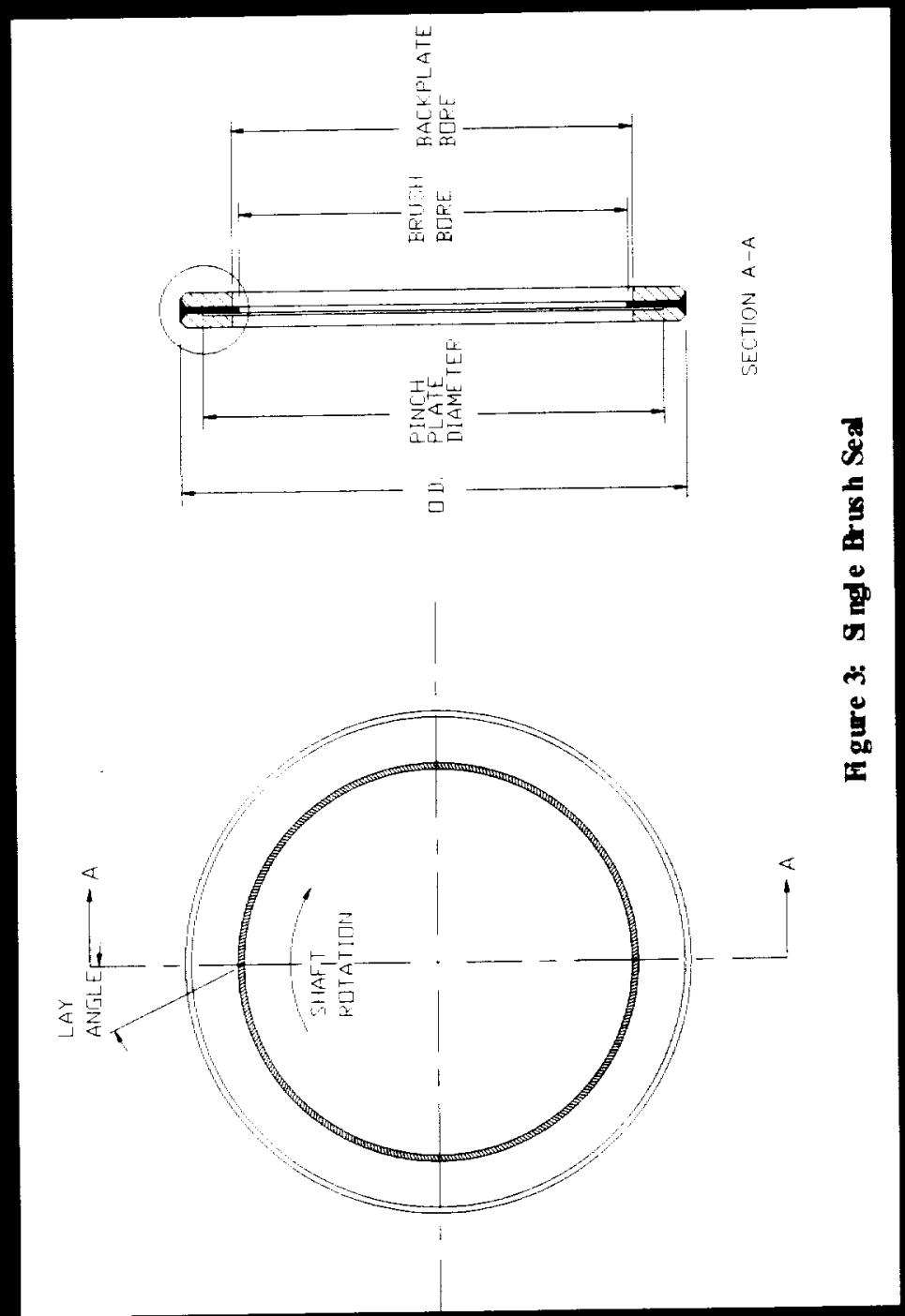

$\frac{\infty}{00}$
0
0
$\frac{0}{0}$
$\frac{1}{0}$ 


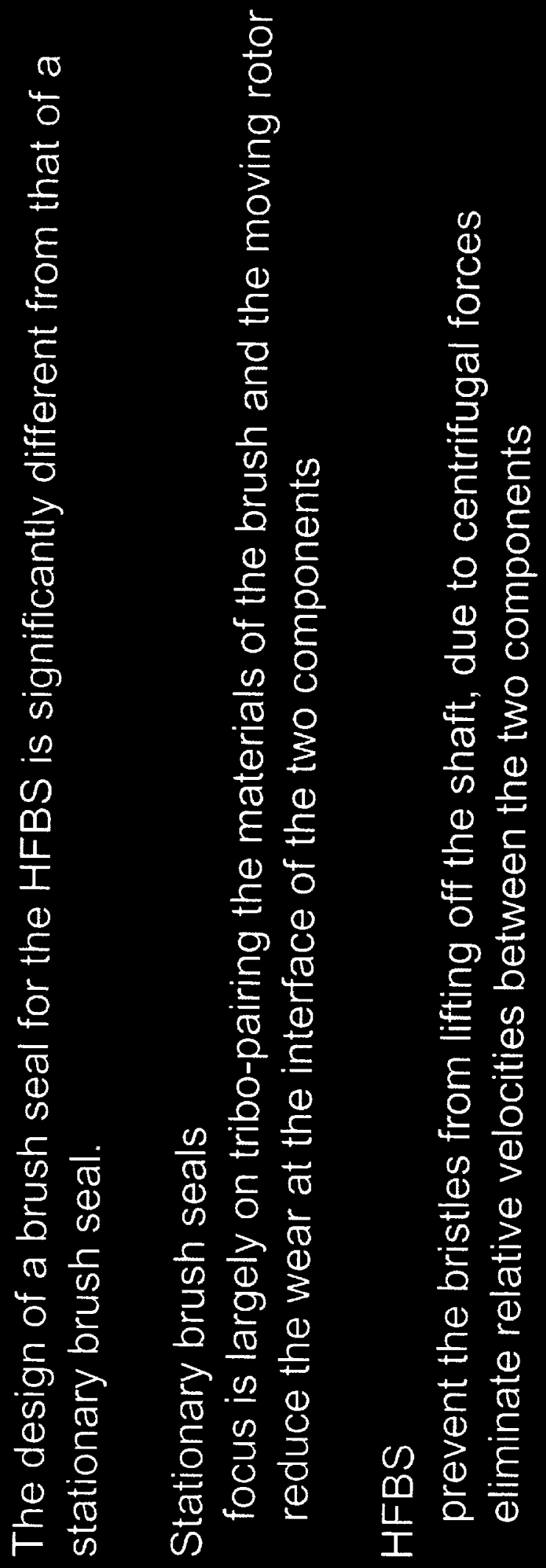




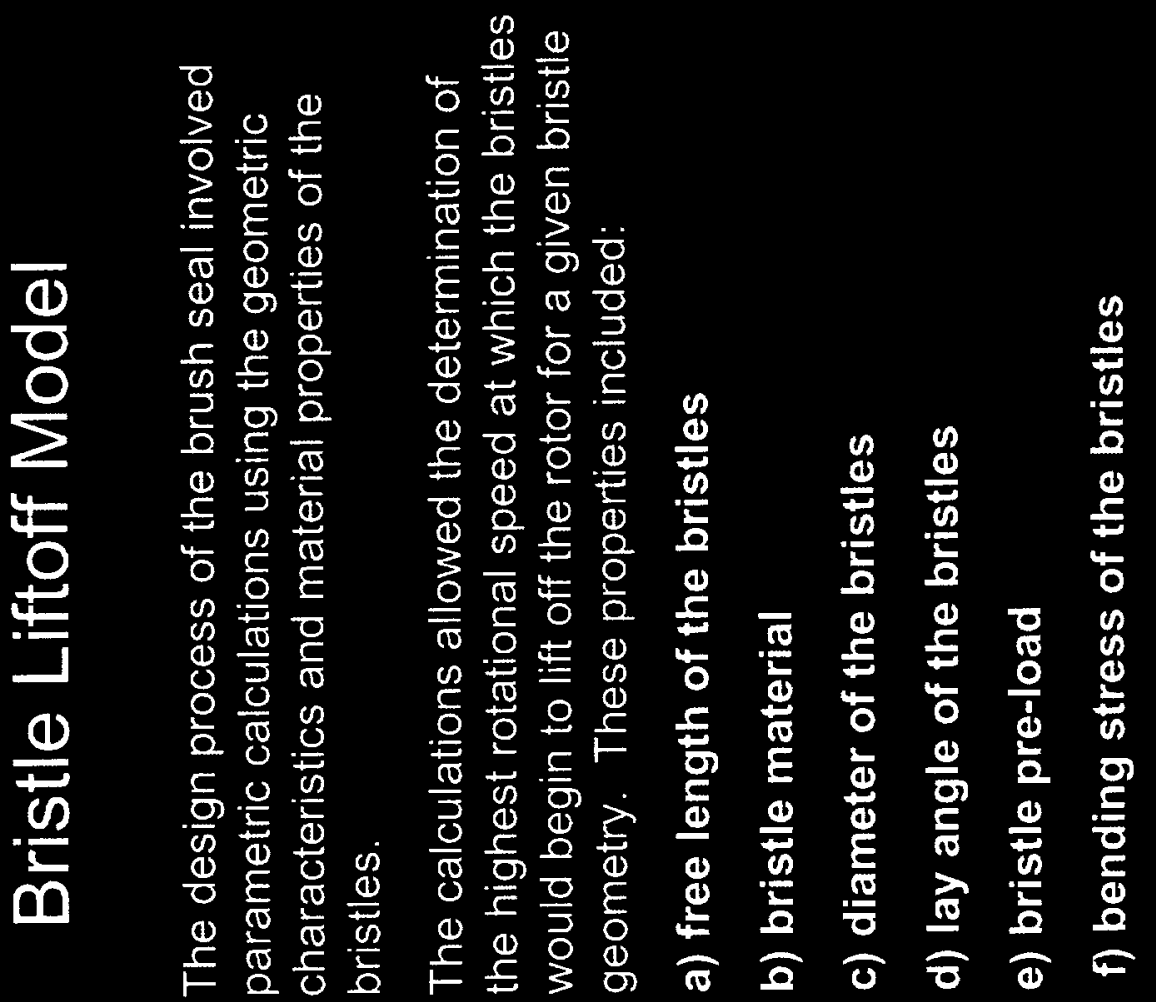



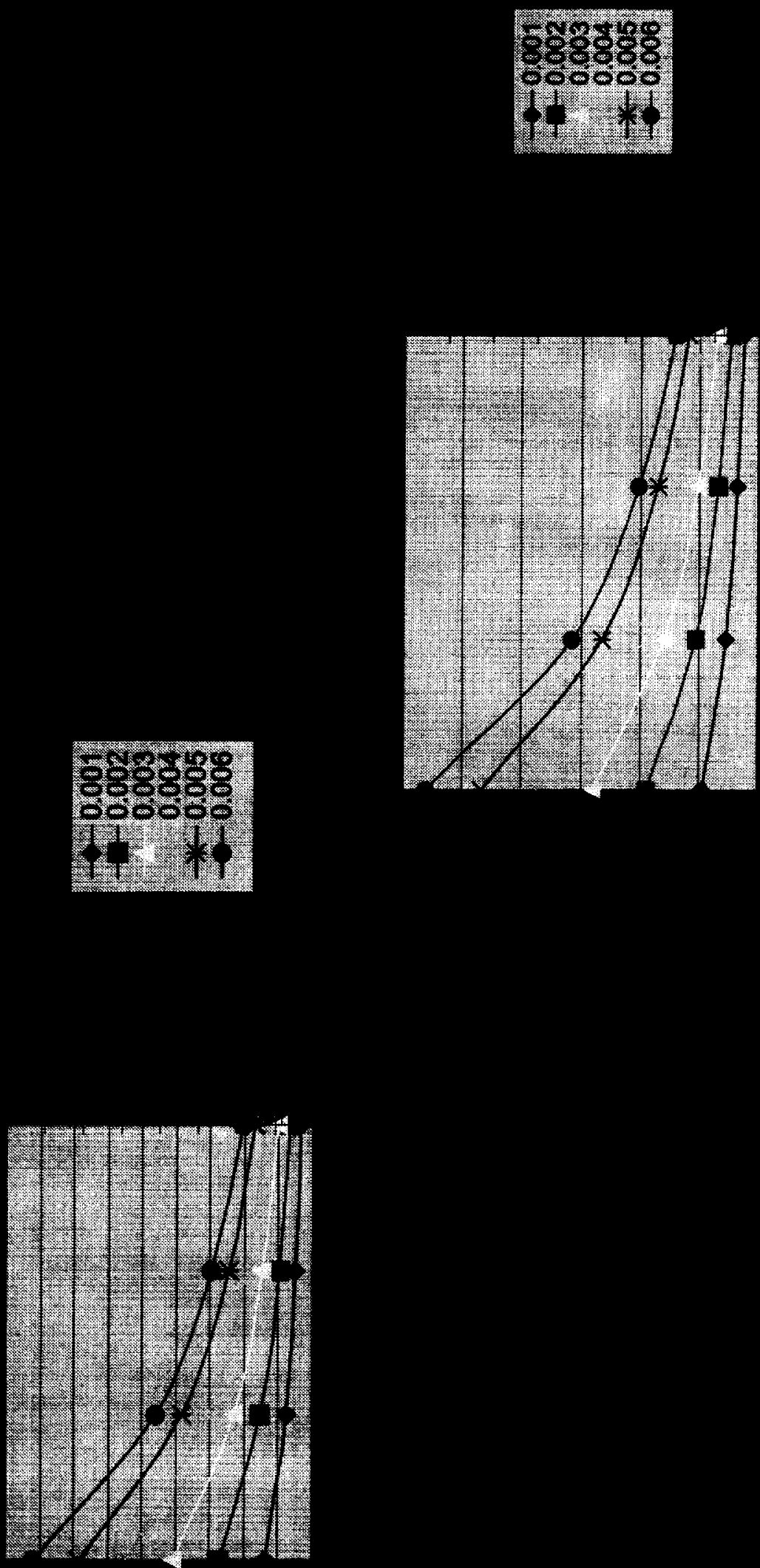

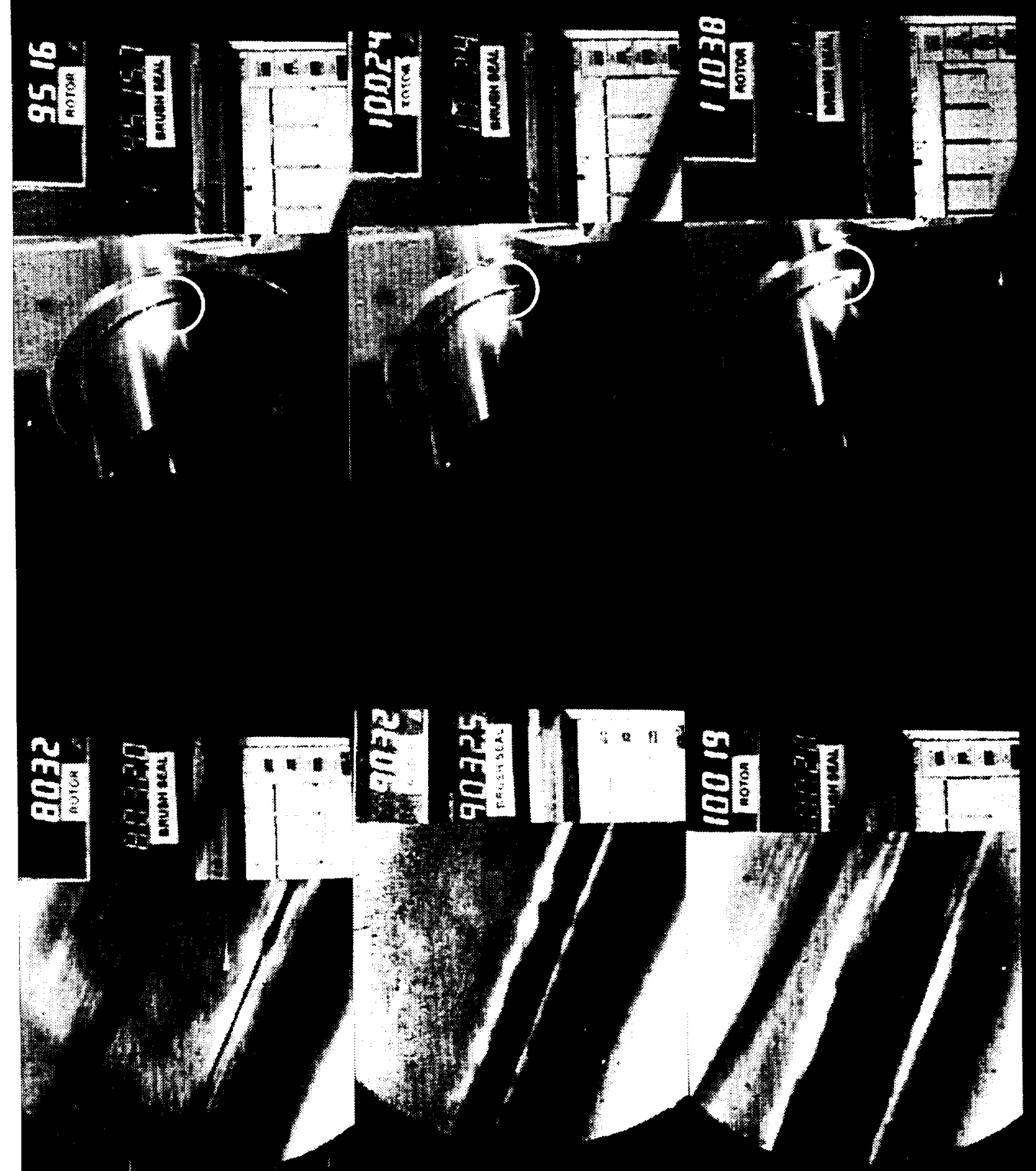


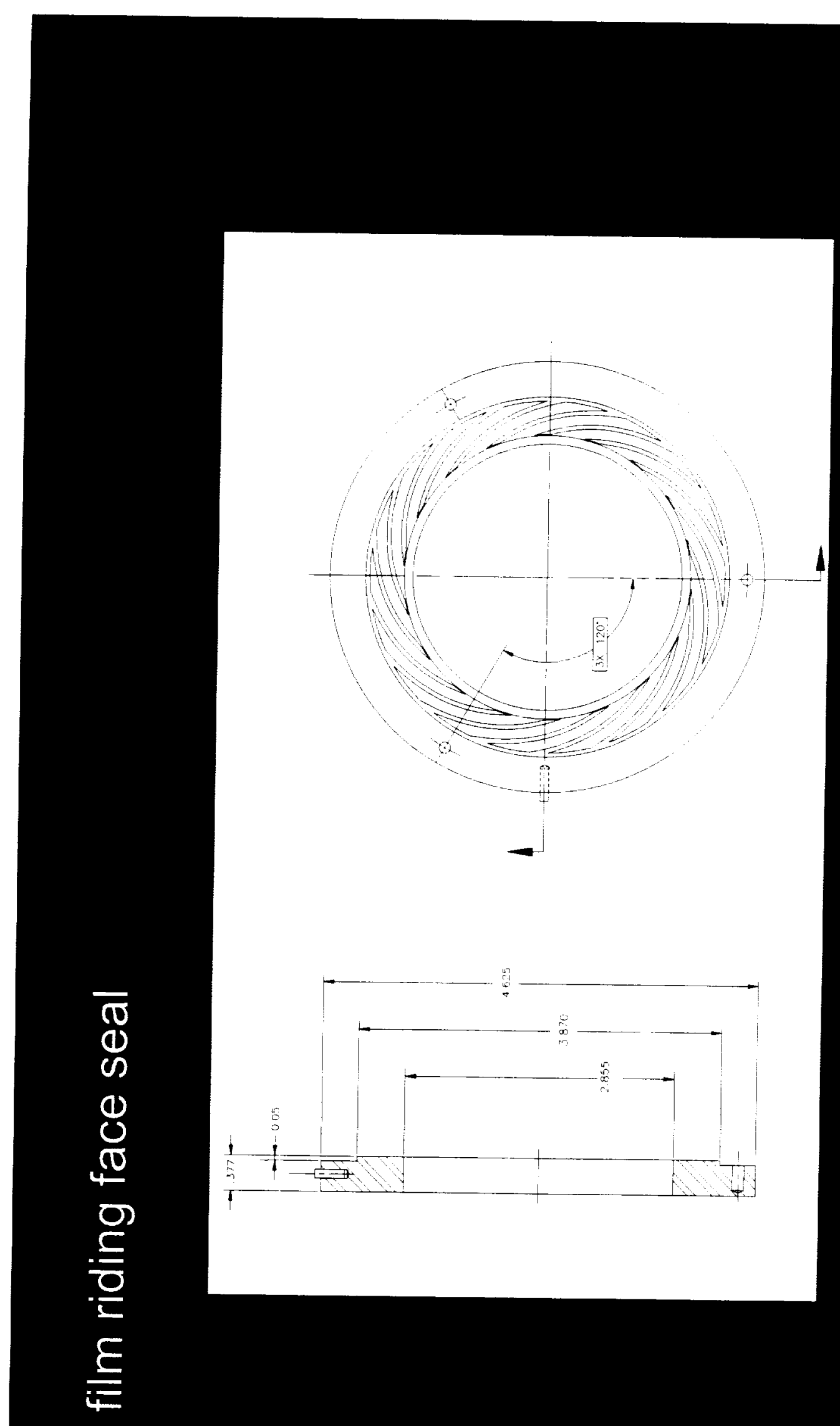




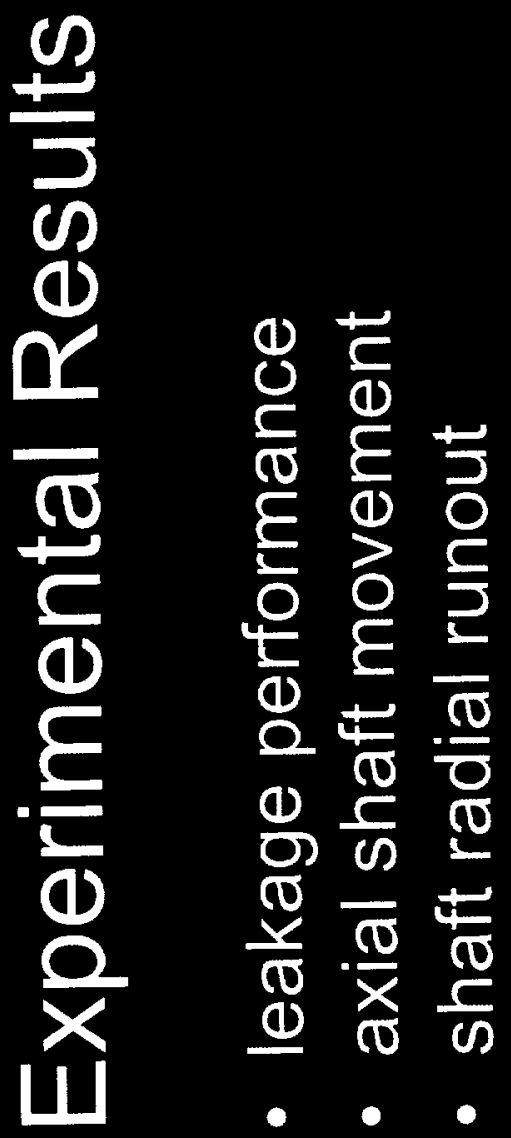




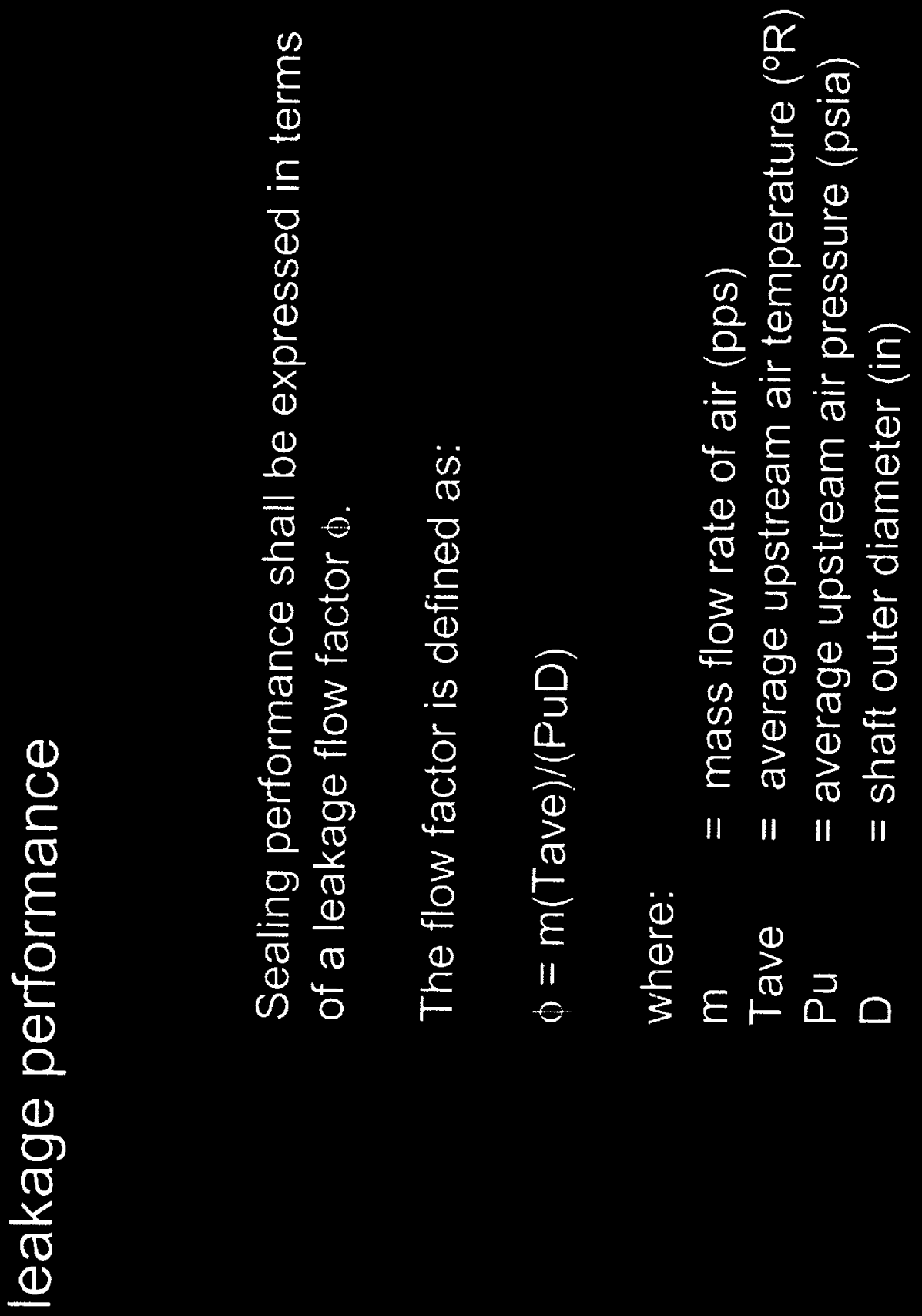




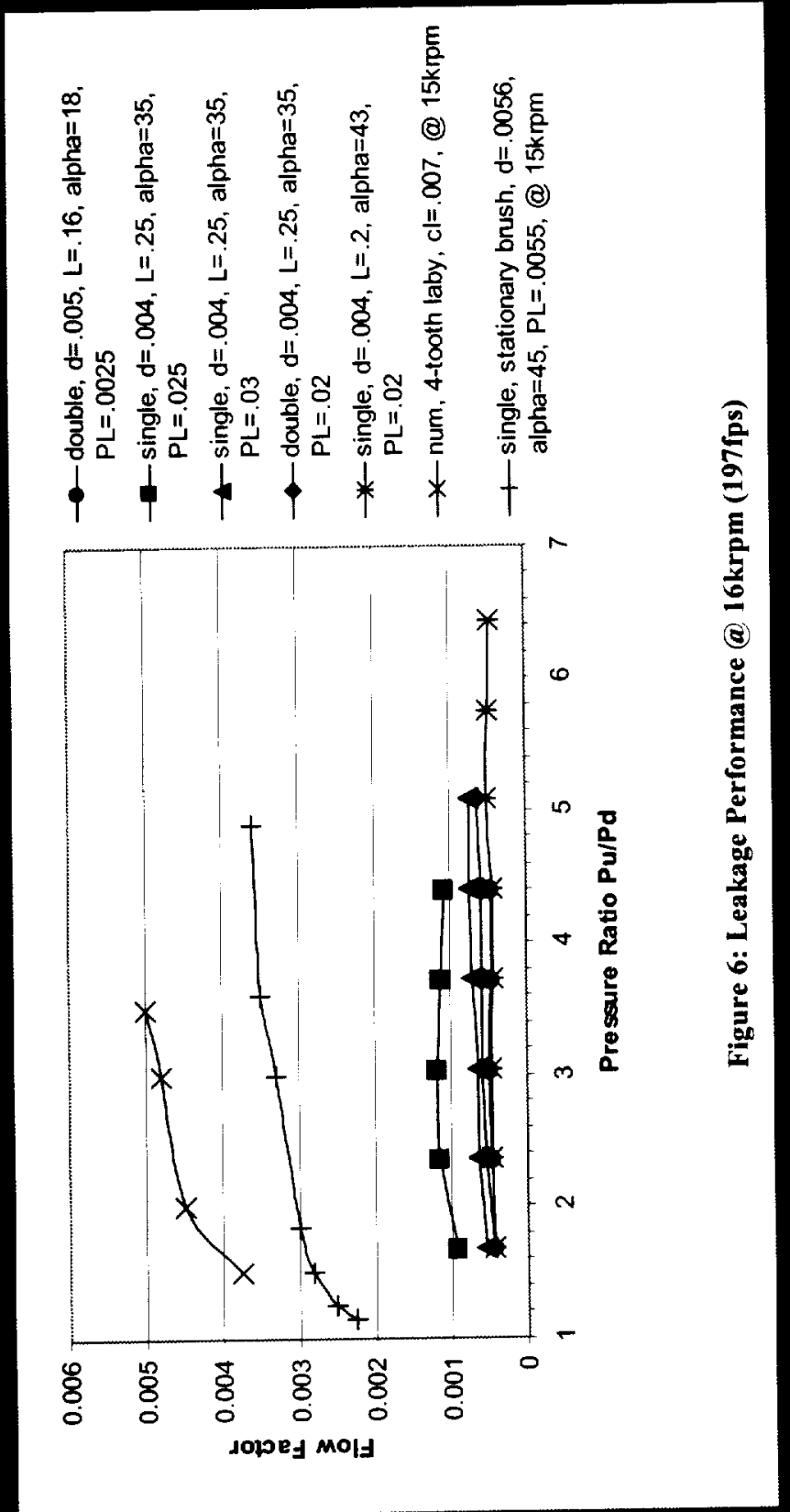



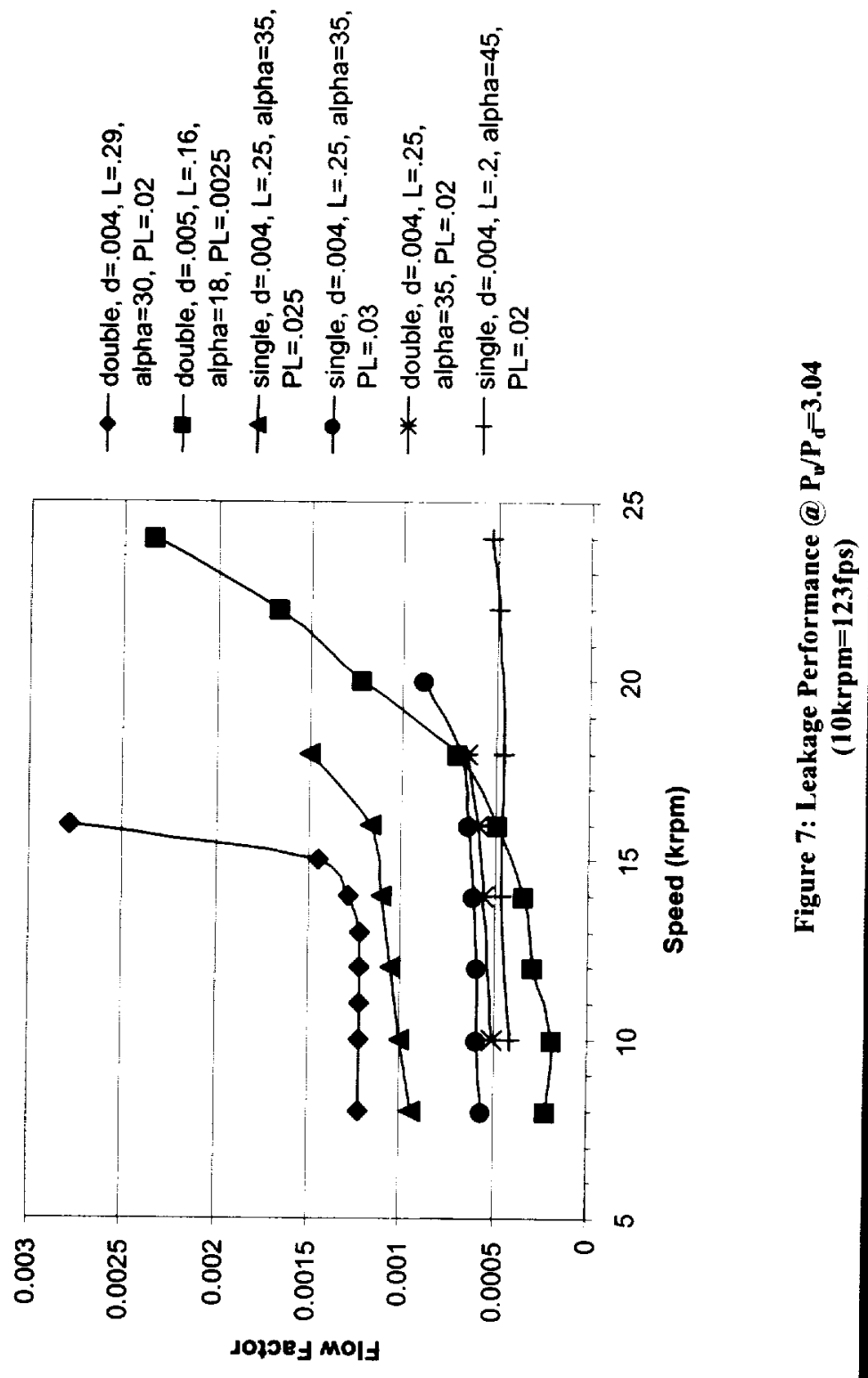


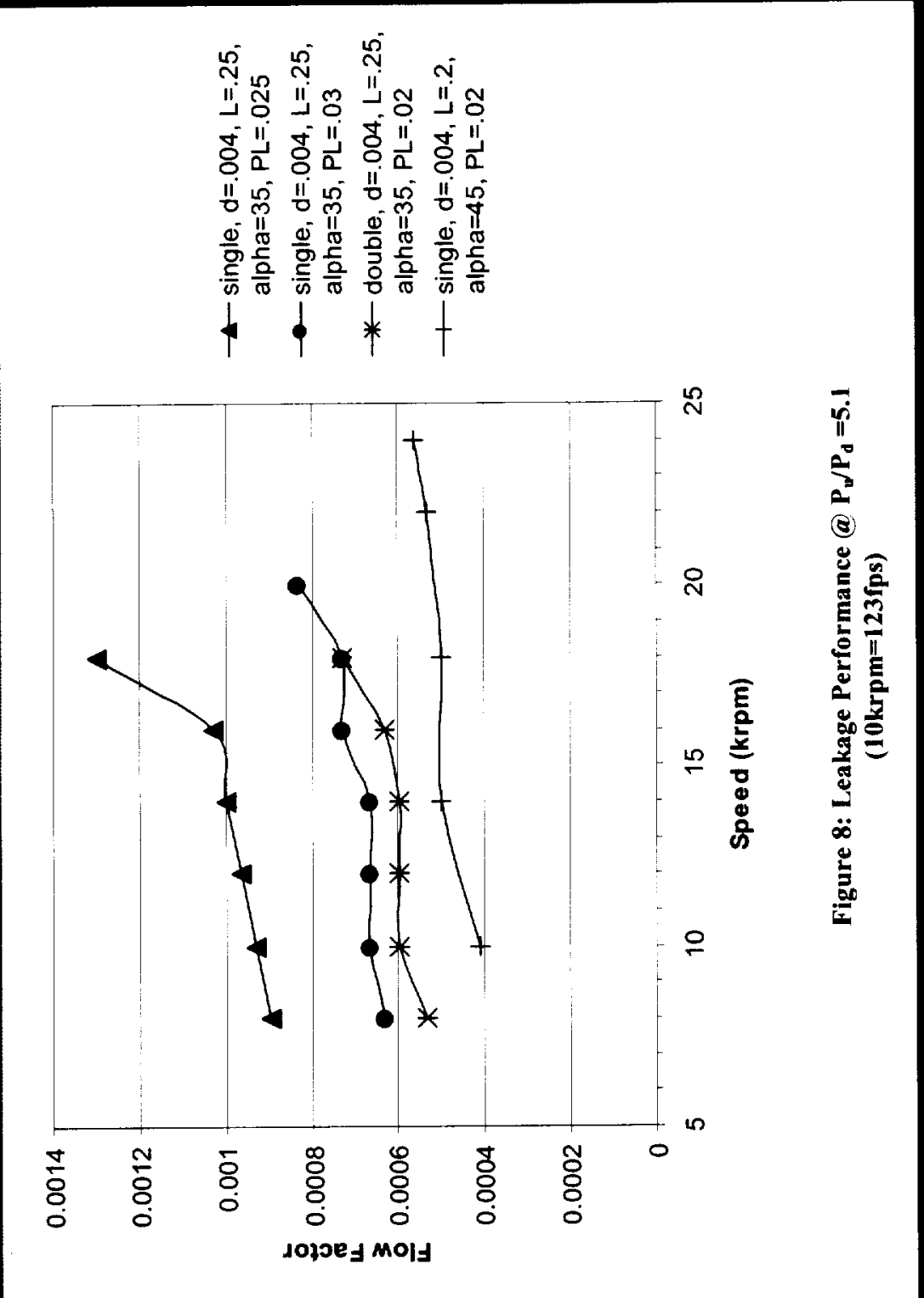




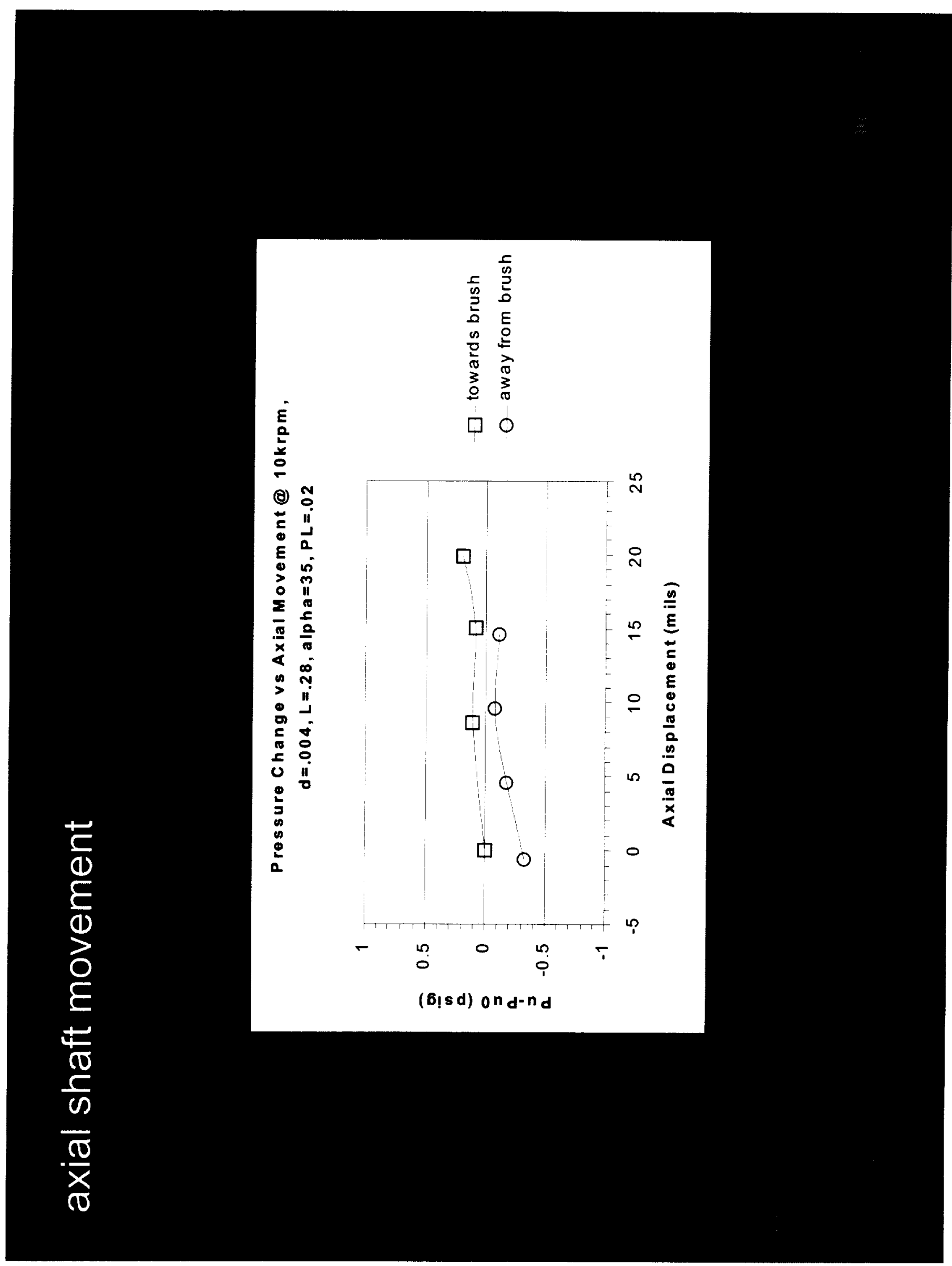




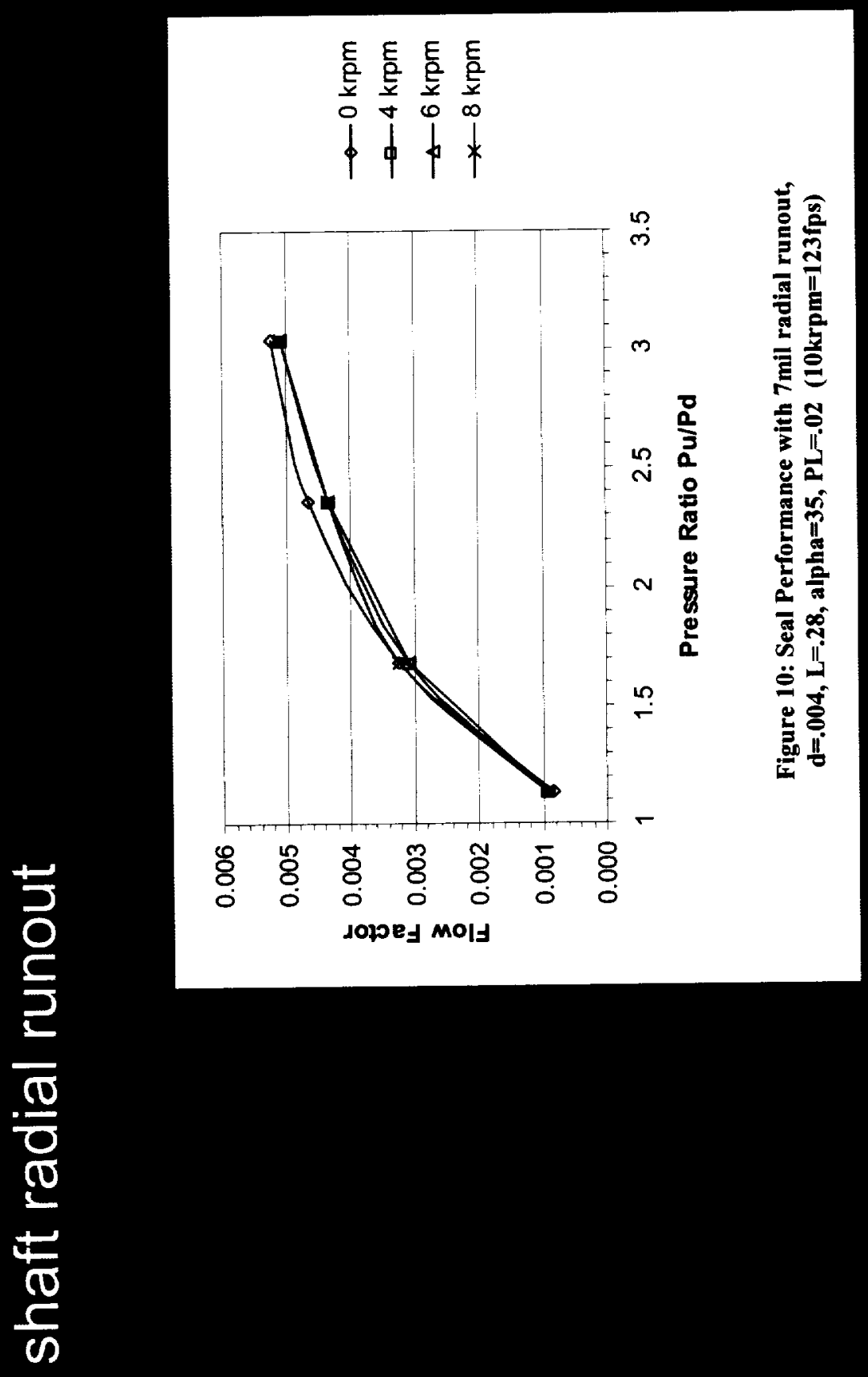




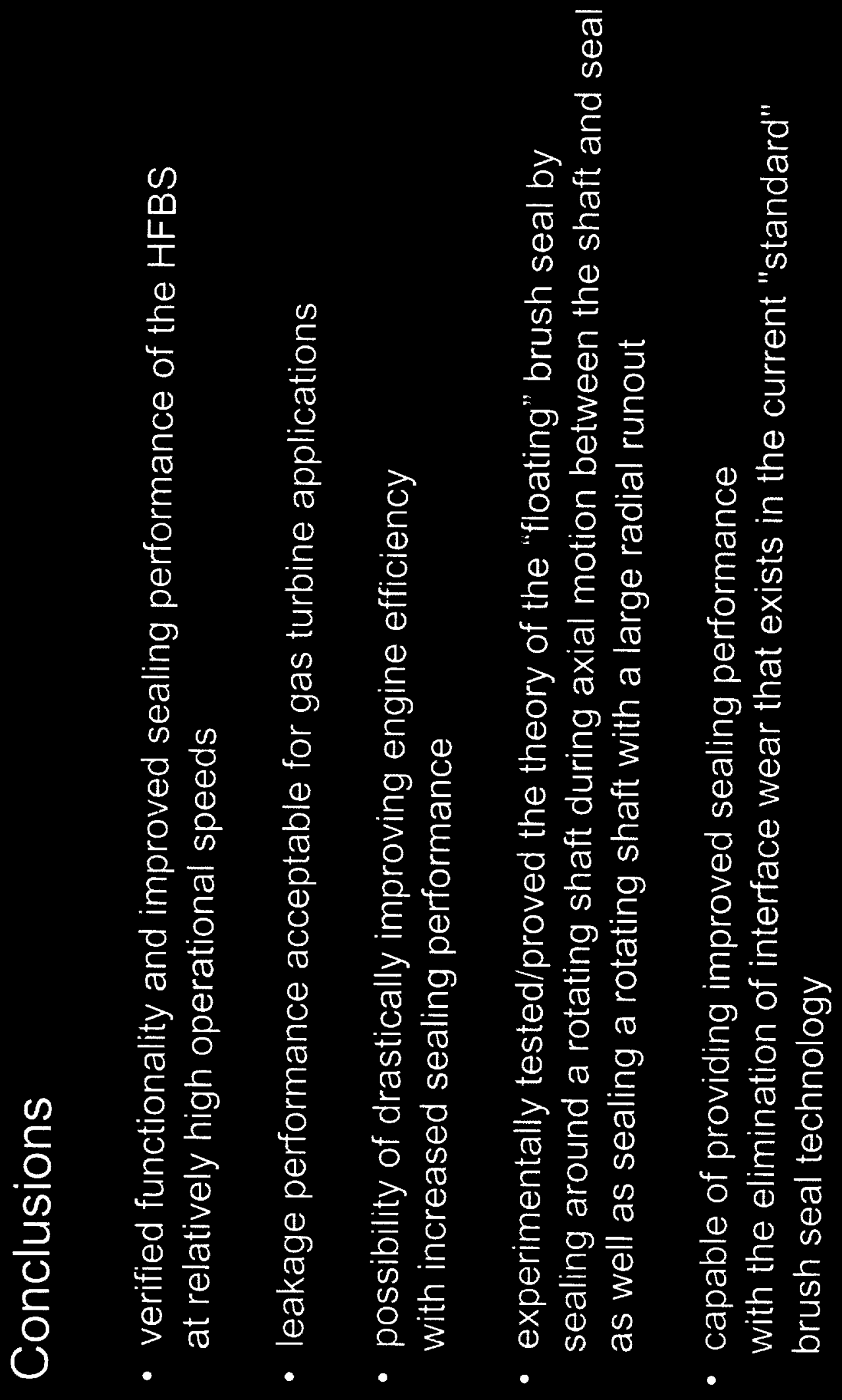

